\title{
Corporate Social and Environmental Reporting in OHADA Context: Evidence from Companies Listed on the Douala Stock Exchange
}

\author{
Alexis Nganthou ${ }^{1}{ }^{*}$ Hamadou boukar ${ }^{2}$ Gaelle Djeugou ${ }^{3}$ \\ 1.FSEGA, Université de Douala, PO 4032, Douala, Cameroun \\ 2.Faculté des sciences économiques et de gestion, Université de Ngaoundéré \\ 3.Université catholique Saint Jerôme, Douala, Cameroun
}

\begin{abstract}
This research questions the capacity of the OHADA accounting system to report on the societal commitment of companies. To carry out such a study, we are interested in the companies of the Douala Stock Exchange, which permanently publish green operations. The analysis was done at two levels: the first level of analysis highlighted the categories of green operations reported by the companies of our sample. The second level of analysis consisted in analysing the financial statements produced by these companies, in order to see in which accounts green transactions are recorded. The analysis reveals that, apart from some additional clarifications to be made in the appendices, the financial statements produced according to OHADA do not specifically highlight green information.
\end{abstract}

Keywords: Green operations, societal commitment

DOI: $10.7176 / \mathrm{RJFA} / 10-24-11$

Publication date: December $31^{\text {st }} 2019$

\section{Introduction}

Initially an object of study in strategic management, Corporate Social Responsibility (CSR) has become a real subject in accounting science. From Sustainable Development ${ }^{1}$ (SD) from which it originates (Brundtland, 1987), CSR relates initially to the responsibility of the businessman towards society (Bowen, 1953), to integrate then problems related to environment's respect (Gray et al., 1996). This "new" concept shifts the initial focus of the organisations, which was to seek maximum profit (Friedman's neoclassical conception) to the pursuit of sustainable profit, balancing both economic performance, social well-being, and respect for the environment (Friedman 1971, Petit and Belet 2013). Consequently, faced with the new social and environmental information to be taken into account, the traditional accounting model finds itself in a mess, and gives free rein to the development of a research problem on how to account for societal commitments of companies.

Prior literature reveals the existence of a number of solutions for translating CSR of organisations. These solutions can be classified in two groups: on the one hand the universal solutions, provided by the standards such as the Global Reporting Initiative (GRI) and the ISO 26000 standard (Grimand et al., 2014, Hahn and Lülfs, 2014), which aim to provide a universal conceptual and normative framework for the processing and communication of green information. And on the other hand, tools applicable to specific regions, which are developed by national or regional standards (NRE, Grenelle, water accounting, etc.).

At a time when African companies are looking for a path towards economic emergence, it becomes appropriate to ask whether the consideration and dissemination of green operations, a current problem and of Western origin is not a luxury for them (Moskolai et al., 2016). Although it is true that the economic fabric of most African states is still embryonic, compared to that of the major Western economies, the dissemination technique of green operations remains problematic both in the Europe and in Africa (Ngantchou, 2015). This insufficiency can be explained by the absence of theoretical and conceptual frameworks which lacks to green accounting (Gray, 2010).

Faced with all these difficulties, it is opportune to focus on how do businesses in OHADA context report on their societal commitment?

The purpose of this study is to analyse the financial statements produced by companies listed on the Douala stock exchange in order to assess the ability of the OHADA model to report on the societal commitment of companies.

The communication is structured around three sections: Section one makes an inventory of the existing

\footnotetext{
${ }^{1}$ Inspired from the law of retaliation, the code of Hammurabi is considered one of the oldest conceptions of the SD (King, quoted by Pastore, 2011). Decreed by the king of Babylon of the same name, this legal code has prevailed for nearly 1000 years. It defines the means of repairing the damage caused by economic activity on nature and people, to reconcile economic sphere and social welfare. An example from this code is as follows: if an architect builds a house and collapses by killing the householder, the architect will be executed; if it is the son of the householder who is killed, the son of the architect will be killed; and if on the other hand it is a domestic animal which is killed, one will also kill an animal belonging to the architect.
} 
models / standards (1), section 2 explains the methodology of the study (2) and the last section presents the findings of the study (3).

\section{1-The standards of green information accounting report: An inventory}

Following the widening of companies' responsibility, the latter are called to account, not only of their financial performance, but also of the impact of their activity on the socio-natural environment. To this end, national and international organisations have set up a battery of tools and methods that enable companies to report on their societal commitment. This section presents the solutions of the international standards and those of the national standards.

\section{1-1- The solutions of the international standards for the diffusion of green operations}

Several solutions inspired by green accounting approaches have been proposed around the world to take into account and disseminate green called operations. We will discuss here the international standard ISO 26000 (11-1) and the Global Reporting Initiative (GRI) (1-1-2).

\section{1-1-1 The international standard ISO 26000}

ISO 26000 is an ISO standard relative to corporate social responsibility, which defines how organisations can and should contribute to sustainable development. It has been published since November 1, 2010.

This is the first international standard on "Guidelines on Social Responsibility". ISO 26000 is at first sight a reference tool, a guide to objectives and good practices. Its purpose is to define the terms of "societal" responsibility at the global level and to find a common terminology for all organisations, with or without profit and whatever their size.

The ISO 26000 standard is not mandatory and does not lead to certification. It is an approach of corporate accountability. Its international nature allows companies that use its standards to disseminate standardized, verifiable and comparable information on their social and environmental responsibility (Grimand et al. 2014).

The main limitation of this standard is related to the format of dissemination of information. Far from reflecting the usual accounting standards (monetary quantification, use of accounts, summary financial statements, etc.), stakeholders criticize the narrative form of reports produced.

Pursuing the same objective as the ISO 26000 standard, another international standard, with its ambition to bring green reporting closer to financial reporting, is increasingly being adopted by companies: this is the GRI standard.

\section{1-1-2- The Global Reporting Initiative (GRI)}

GRI is an international institution whose mission is the establishment and dissemination of guidelines for the publication of environmental and social reports. It comes from an initiative launched in 1997 by CERES (Coalition for Environmentally Responsible Economies) in partnership with the United Nations Environment Program (UNEP). GRI is presented as a multi-stakeholder organisation that aims to raise the quality of societal reporting "to a level of comparability, rigor and verifiability equivalent to that of financial reporting". Like accounting standardization, the existence of a "generally accepted" framework and rules is one of the conditions for trust between the various stakeholders. It allows an assessment of performance over time and within a sector, and it structures the internal information system. It should be noted that the adoption of the GRI standard is voluntary and that there is currently no provision requiring its application (Alonso-Almeida et al., 2014, Chauvey and Naro, 2013).

However, the GRI initiative remains limited. Literature identifies three important limitations to the ability to translate the experience of accounting standardization into societal reporting. First, there is the voluntary nature of the approach, and the multiplicity of intended recipients which confer to the report a communicative function. Secondly, the proposed reference framework focuses more on stakeholder management than on the surrender function; and finally, the proposed tools are far from having the robustness of the accounting model (Marimon et al., 2012, Milne and Gray, 2013).

In a perspective similar to that of international standards, national and / or regional standards also try to propose solutions for the report of green information

\section{1-2 The solutions of national and regional standards for green information reporting}

Non-universal solutions intended to provide companies with tools for reporting their externalities include regional accounting standards such as IAS-IFRS and national standards designed to solve specific problems, as it is the case of standards for water accounting in Australia. These solutions are often accompanied by a set of laws and legal rules governing in a more or less strict manner the accounting report of green information of companies. We will first talk about water accounting in Australia, and finally the NRE and GRENELLE laws in France.

\section{1-2-1- Water Accounting: A water accounting management Programme in Australia}

Given its predominantly semi-arid conditions, drought propensity and dependence on agricultural production, 
Australia faces significant water problems (Pigram, 2007). Clearly, the successful housing of the world's second driest continent would depend largely on effective water management (Carroll 2008, Edwards 2013, Vardon and Peevor 2004).

The National Water Initiative was designed to harmonize many aspects of water management nationally. This included a call for consistent water resource accounting to produce standard water information that can be compared and reconciled. The objective of water resource accounting is to support the confidence of governments and investors in the quantity of water exchanged, extracted for consumption, recovered and managed for environmental results, and other public benefits (Council Australian governments, 2004, paragraph 80 ). The need to have a water accounting system that builds confidence in the growing water market has been one of the reasons for applying the financial accounting approach to the accounting of the water. After all, financial reporting is generraly designed to support confidence in financial markets (Tello et al., 2016).

Water accounting has thus become an evolving discipline and part of a larger national program to improve Australia's water resources management. While water accounting is an increasingly popular topic in social and environmental accounting, only a handful of studies have examined it (Ahmad et al., 2010, Chalmers et al., 2012, Godfrey et al. Chalmers, 2012, Slattery et al., 2012, Sofocleous, 2010). Ahmad et al. (2010) analyzed what was revealed by the Australian water authorities, and conclude that their disclosures provide only limited information on water issues, including quality and assessment. These authors do not deny, however, the ability of this model to master the consumption of water resources. However, mastering this model requires skills in engineering, mathematics and statistics. This feature makes it difficult to apply this model in developing countries.

We end the presentation of these standards of diffusion of green information in the world by the presentation of the impact in France of the laws NRE and GRENELLE.

\section{1-2-2 The NRE and GRENELLE laws in France}

Under the combined effect of globalisation and the increasingly urgent need to control the social and environmental impact of businesses, the French legislator has implemented a set of regulatory batteries including the NRE law and the Grenelle laws 1 and 2.

\section{- NRE law}

Published in the Official Journal on May 15, 2001, the law on New Economic Regulations, commonly known as the NRE law, aims to reduce the harmful effects of internal dysfunctions and globalization. Based on a requirement for transparency of information, this law obliges French companies to present in the annual report, in addition to their accounting and financial information, data on the environmental and social consequences of their activities ${ }^{1}$. The NRE Act entered into force by decree on February 20, 2002 and has been effective since January 1, 2003 for fiscal years beginning on or after January 1, 2002 (Chauvey, 2010, Chauvey et al., 2015, Chelli, 2015). Chelli and Gendron, 2015, Damak Ayadi, 2006, Damak-Ayadi, 2010).

We note here, the will of the French legislator to gradually integrate into the scope of financial accounting, "green" information long ignored by the regulations. This law results in the combined publication (in the same document) of financial and societal information, which was not the case before. In fact, many companies were already publishing voluntary reports in addition to the mandatory financial statements, justifying their efforts for sustainable development. These narrative-style reports report information that is usually difficult to verify, which lead them to be nicknamed "greenwashing" ${ }^{2}$ documents (Bowen and Aragon-Correa, 2014). The listed companies have thus included in the annual report, in accordance with the regulations (NRE law), information on the social and environmental impact of their activities.

The main remark to be made is the form of the information reported, which, far from reflecting the dissemination standards of accounting stricto sensus, is closer to a hybrid "reportage" ${ }^{3}$ mixing accounting and communication of "tales" (Capron and Quairel, 2009). The other limits of the NRE law concern: the absence of sanctions; the lack of control devices; and the lack of a precise definition of the scope concerned (holding company or group / global or national). The Grenelle law complements the provisions of the NRE law

\section{Grenelle 1 and 2 laws}

Regarding CSR, the Grenelle I and II laws are directly in line with the NRE law, which they intend to broaden the scope of application and improve the content of the information to be communicated (Blin-Franchomme, 2010; Blin-Franchomme and Desbarats, 2010, Blin-Franchomme et al., 2011).

Thus, while the NRE law only concerned companies listed on the stock market, it is now companies whose balance sheet total or turnover and the number of employees exceed the thresholds set by decree in Council of State, the credit institutions, investment firms and financial companies, regardless of their legal form, and mutual insurance companies that must communicate their societal policy. There is therefore a rather remarkable

\footnotetext{
${ }^{1}$ http://www.rsenews.com/public/dossier_eco/loi-nre.php?rub=1 consulted on the $20^{\text {th }} / 04 / 2017$

${ }^{2}$ Account laundering or green washing: a corporate policy that aims to communicate the company's initiatives for the environment in order to hide the reality of their negative impact on society and nature.

${ }^{3}$ Michel Capron, Françoise Quairel, « Le rapportage « développement durable » entre reddition et communication, entre volontariat et obligation », Revue de l'organisation responsable 2009/2 (Vol. 4), p. 19-29
} 
extension of the reporting obligation. In addition to extending the scope of reporting requirements, the Grenelle II law aims to improve the content of information.

Finally, the law provides for an unprecedented control of the information that will be issued by the company. A new paragraph of Article L. 225-102-1 of the French Commercial Code now provides that "the social and environmental information that appears or must appear in relation to legal and regulatory obligations is subject to verification by a third independent party, in accordance with procedures laid down by a decree taken during the state council. This audit gives rise to an opinion which is sent to the stockholders assembly at the same time as the report of the board of directors or the executive board ". This body will not only have to certify that the information required by the law and the regulation have been communicated, but it will also give a reasoned opinion on "the sincerity of the information contained in the management report". The report must also mention the diligences that the organisation has implemented to carry out its audit mission. It is therefore not only a matter of attesting of the presence of the requested information, but also of their authenticity. In addition, an important application deadline is left to unlisted companies, since this control should only be applied for the years ended December 31, 2016 (Blin-Franchomme, 2010, Damak-Ayadi, 2010).

Finally, even if the Grenelle laws are more demanding, the fact remains that the form of information disseminated is closer to the narrative than to accounting in the strict sense of the term. The information disseminated is difficult to verify, and the financial statements produced according to the Grenelle laws always have a series of narratives supplemented by tables of quantities and percentages.

After having presented the main standards of green information report in the world, let us now turn to the case of the OHADA accounting framework to know its positioning in this literature.

\section{1-2-3 The SYSCOHADA and the publication of green information}

After the presentation of the solutions of global standards to internalize and disseminate green information, let us look now at the positioning of the OHADA accounting system on the management of this type of information.

Long remained static in the face of social and environmental changes in the socio-political context of African companies, OHADA finally offers companies the tools to integrate and communicate in a specific way on their consideration of social and environmental problems. For example, the recent inclusion in the OHADA Uniform Act of the treatment of provisions, contingent liabilities and assets within the scope of corporate responsibility, shows the interest that OHADA now gives to social and environmental issues. By mimicry of international standards IAS-IFRS, OHADA opts for the monetary quantification of the social and environmental information (SEIs) by prescribing accounting methods specific to problems hitherto excluded from its operating framework. In doing so, OHADA seems to converge towards the research axis advocating the adoption of a single model for the diffusion of SEI (monistic approach). By requiring companies to give a certain number of details on certain specific transactions, OHADA completes the published green information with details in "appendices". In a proactive way, companies should start to adapt to the new features introduced in the new uniform act (Diawara and Lavallée, 2014, Ndjetcheu, 2013, Takafo-Kenfack, 2018).

Note 35 is undoubtedly the greatest innovation introduced by SYSCOHADA to reflect the social and environmental commitment of companies. In this appendix, companies with a workforce of more than 250 employees have the obligation to communicate information about their taking into account of environment and men (Safari and Nathalie, 2018). 
Figure 1 : Social and environmental information to give (SYSCOHADA)

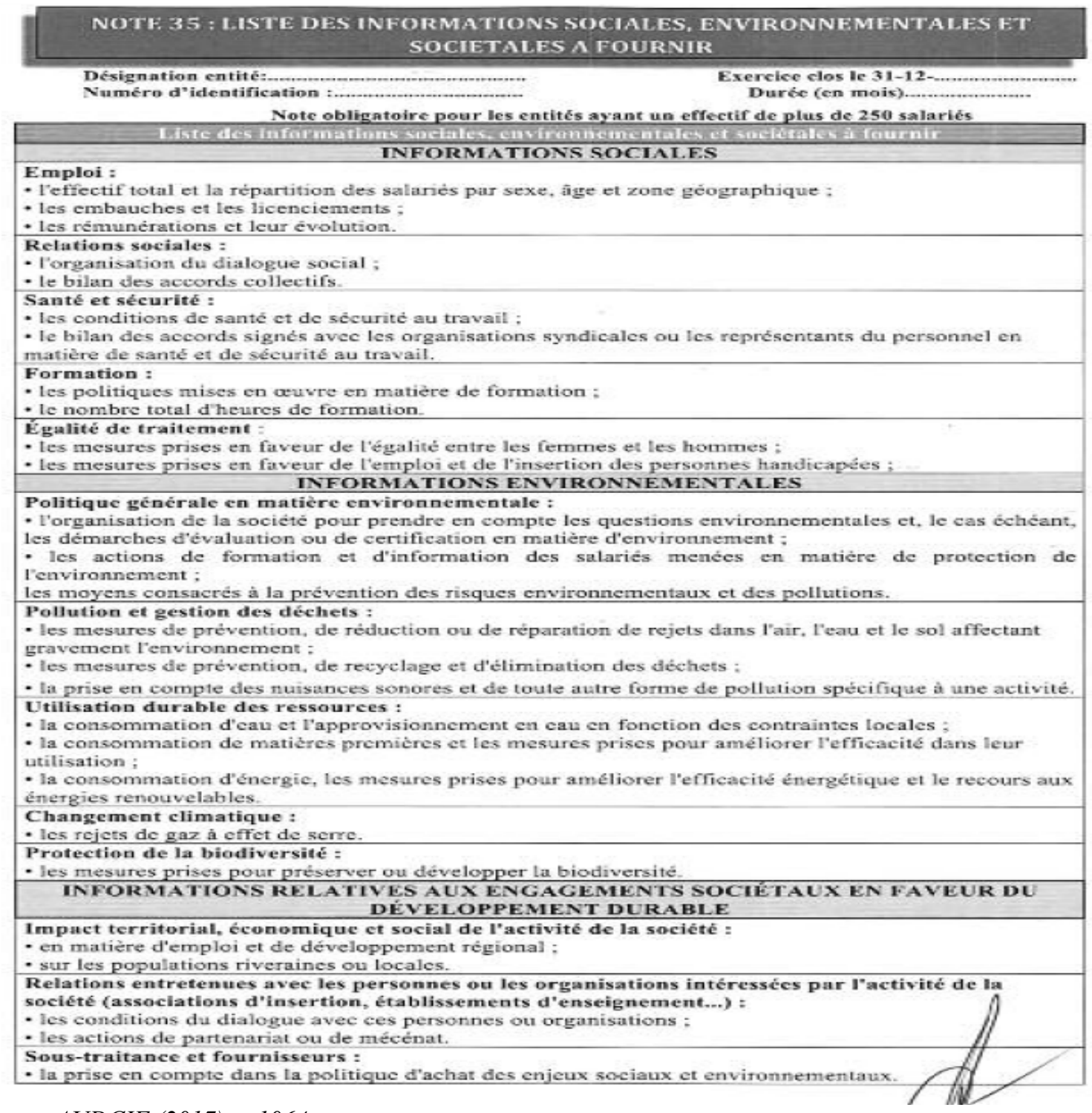

Source: AUDCIF (2017), p.1064

Even if we note a real advance in the integration of data hitherto ignored by OHADA, it is clear that OHADA does not provide any details on how this information should be evaluated.

In this part, we presented the diffusion standards of green information. With no ambition to make a complete review (which would be quite complex), we presented the most usual, taking care to specify some of their limitations. It appears from this analysis that most of these accounting frameworks adopt a narrative style to report SEI. However, given the benefits of the financial accounting model (reliability, verifiability, universality ...) efforts continue to be made to achieve a better designed accounting for green information.

After having presented the innovations brought by the new OHADA uniform act, it is important to understand how companies subject to this standard, account for social and environmental information. For this purpose, some methodological elements are explained in the second part.

\section{2- The methodology of the study}

This study investigates whether the financial statements produced by Cameroonian companies from the OHADA accounting model reflect their societal commitment. To do this, we start from the analysis of websites to identify the social and environmental information diffused. Subsequently, we analyze the financial statements produced by these companies to find out in which accounts this information is recorded. The purpose of this study is to evaluate the capacity of OHADA to translate the societal commitment of companies.

To carry out such an analysis, the choice of data collection and analysis strategy is crucial. This section will discuss then the data collection (2-1) and analysis (2-2) strategy. 


\section{2-1 Data collection strategy}

At a time when African companies are looking for a path of economic emergence, it becomes appropriate to ask whether the consideration and diffusion of green operations, a current problem and of Western origin is not a luxury for African companies. Although it is true that the economic fabric of most African states is still embryonic, compared to that of the major Western powers, the way of reporting green operations remains problematic both in the Europe and in Africa.

To this end, conducting a study on the diffusion of green operations in Cameroon requires firstly to choose companies with data available on the internet and second, to be able to obtain the financial statements produced by these companies according to the requirements of SYSCOHADA. However, some difficulties related to the context make it difficult to obtain such a sample. For example, Internet culture is not yet widespread in all companies in Cameroon. Similarly, Cameroon does not yet have a balance sheet centralisation organism to easily obtain the financial information of companies. For all these reasons, we oriented the study towards the Douala Stock Exchange (DSX), which has not only a database of financial information of companies listed there, but also benchmarks to facilitate the identification of green operations disseminated by these companies.

Thus, after presenting the companies listed on that stock exchange (2-1-1), we proceed by the description of the financial statements produced by these companies (2-2).

\section{2-1-1 The presentation of companies listed at the Douala Stock Exchange (DSX)}

The DSX has three listed companies, namely Cameroon Mineral Water Corporation (SEMC), SAFACAM and SOCAPALM.

\section{The Cameroon Mineral Water Corporation (SEMC)}

The first Cameroonian company operating and bottling natural mineral water, the Cameroon Mineral Water Company (SEMC), created on January 16, 1979, started the exploitation and marketing of natural mineral water Source Tangui in October 1983. On June 30, 2006, the SEMC ranked at the top of the list of companies listed on the DSX. Located at $70 \mathrm{~km}$ north-west of Douala, the SEMC is an important stakeholder in the development of the municipality of Mombo.

\section{The SAFACAM company (Société Africaine Forestière et Agricole du Cameroun)}

SAFACAM's head office is in DIZANGUE-PREFECTURE D'EDEA (SANAGA MARITIME). It is a private limited company with a Board of Directors, subject to the provisions of the OHADA Uniform Act on Commercial Company. SAFACAM was created on November 13 and December 3, 1962 for a life of 99 years from the date of constitution. It is then supposed to end its life in 2061. It is registered in the Trade and Credit Register of EDEA under the number 195. Its taxpayer number is: M126200000967-B

\section{The SOCAPALM company}

Socapalm (Cameroon Company of Palmeraies) is an agro-industrial company operating in Cameroon. It is the largest palm oil company in the country, managing plantations on some 78,529 hectares in Mbongo, Dibombari, Mbambou, Edéa, Kienké and Eséka, 32,500 hectares directly exploited and 18,265 hectares indirectly exploited via family plantations. The Socapalm group has 3,200 employees, 2,338 outgrowers who would themselves have 3,000 farm workers. In total, nearly 30,000 people are reported to be Socaplam dependents.

These three companies are listed on the DSX and regularly provide information on the impact of their activities on their socio-natural environment. In addition, they prepare the financial statements annually in accordance with the requirements of the OHADA Uniform Act.

\section{2-1-2 Financial statements}

These financial statements include: the balance sheet, the income statement, the appendices, the financial table of employments and resources (henceforth referred to as the Cash Flow Statement). All of these documents constitute what could be described as an annual report in French jargon. However, given the absence of a balance sheet's centralising body in Cameroon, companies are not required to prepare financial statements except the document required by the tax authorities. This document is commonly known as the Statistical and Tax Statement (in french déclaration statistique et fiscale).

The ability to report green information, as well as the regular production of financial statements makes these companies a rich field for the studied research problem.

\section{2-2 The data analysis strategy}

In order to evaluate the ability of OHADA to translate the corporate social commitment, we conduct an exploratory survey of companies listed on the DSX. The methodology of this survey is based on the comparison between the green information disseminated via the Internet by companies listed on this stock exchange, and the financial statements produced by them. We use as methodological tools the observation and the visual analysis of the financial statements, to identify any informative signal on the societal commitment of these companies.

Our methodological approach, based on the analysis of the accounting diffusion of green information of companies listed at the DSX (SOCAPALM, SEMC, SAFACAM) is organised in two phases namely: the analysis of the societal communications starting from the Internet sites and the data available on the DOUALA 
stock exchange; and the analysis of the financial statements obtained on the Douala Stock Exchange (financial statements for the period 2011-2015).

In the first phase, we went through the search engines in order to identify a set of green information disseminated by companies listed on the DSX. Then we tried to get the financial statements released by these companies. By observing the data and a simple visual analysis, we tried to identify among the masses of accounts of the financial statements, those that could contain the green information identified on the internet. The idea is not to do an exhaustive search for the green information disseminated, but to try from a few observations to identify a signal sent by the financial statements to reflect the societal commitment of the latter.

For the identification of green information we referred to the grids proposed by Ernst and Ernst (1978), combined with the data of the ISO 26000 standard. The main themes of societal information dissemination on which the original study of Ernst and Ernst (1978) are based upon include: the natural environment, energy, fair business practices, human resources, community involvement, products, other information related to corporate social responsibility (Sethi, 1979).

\section{3- Findings}

The data collection phase has identified a lot of green information. Thus, after analyzing the websites we were able to obtain the green information disseminated by the companies in our sample. These are recorded in the table below

Table 1 : Information reported by companies

\begin{tabular}{|l|l|l|l|}
\hline ENVIRONMENT & HUMAN RESOURCES & PRODUCTS & CIVIL SOCIETY \\
\hline $\begin{array}{l}\text { Environnemental } \\
\text { impact studies }\end{array}$ & $\begin{array}{l}\text { promotion of employee's } \\
\text { health and safety }\end{array}$ & $\begin{array}{l}\text { informations related to permanent } \\
\text { improvment of products }\end{array}$ & Construction of roads \\
\hline Environmental audits & $\begin{array}{l}\text { Taking care of sick } \\
\text { employees }\end{array}$ & Research and development & construction of schools \\
\hline Recycling & $\begin{array}{l}\text { Improvment of global } \\
\text { working conditions }\end{array}$ & Certifications & Donations \\
\hline & Training & Quality control & Awareness campaigns \\
\hline
\end{tabular}

\section{Source : Field work, 2019}

Following the identification of the green information disseminated by the companies in our sample, we conducted a visual analysis of the financial statements produced by them from 2013 to 2017 . The analysis focused on balance sheets and income statements ${ }^{1}$. The balance sheet and income statement extracts are presented below as an illustration.

\footnotetext{
${ }^{1}$ We were unable to obtain the financial statements of companies listed on the DSX on the internet. We then went to the DSX headquarters in Douala where we were able to obtain copies of the BALANCE SHEETS and INCOME STATEMENTS of listed companies.
} 
Table2: Extract from SOCAPALM balance sheet, year 2013.

\section{SECTION I : LE BILAN}

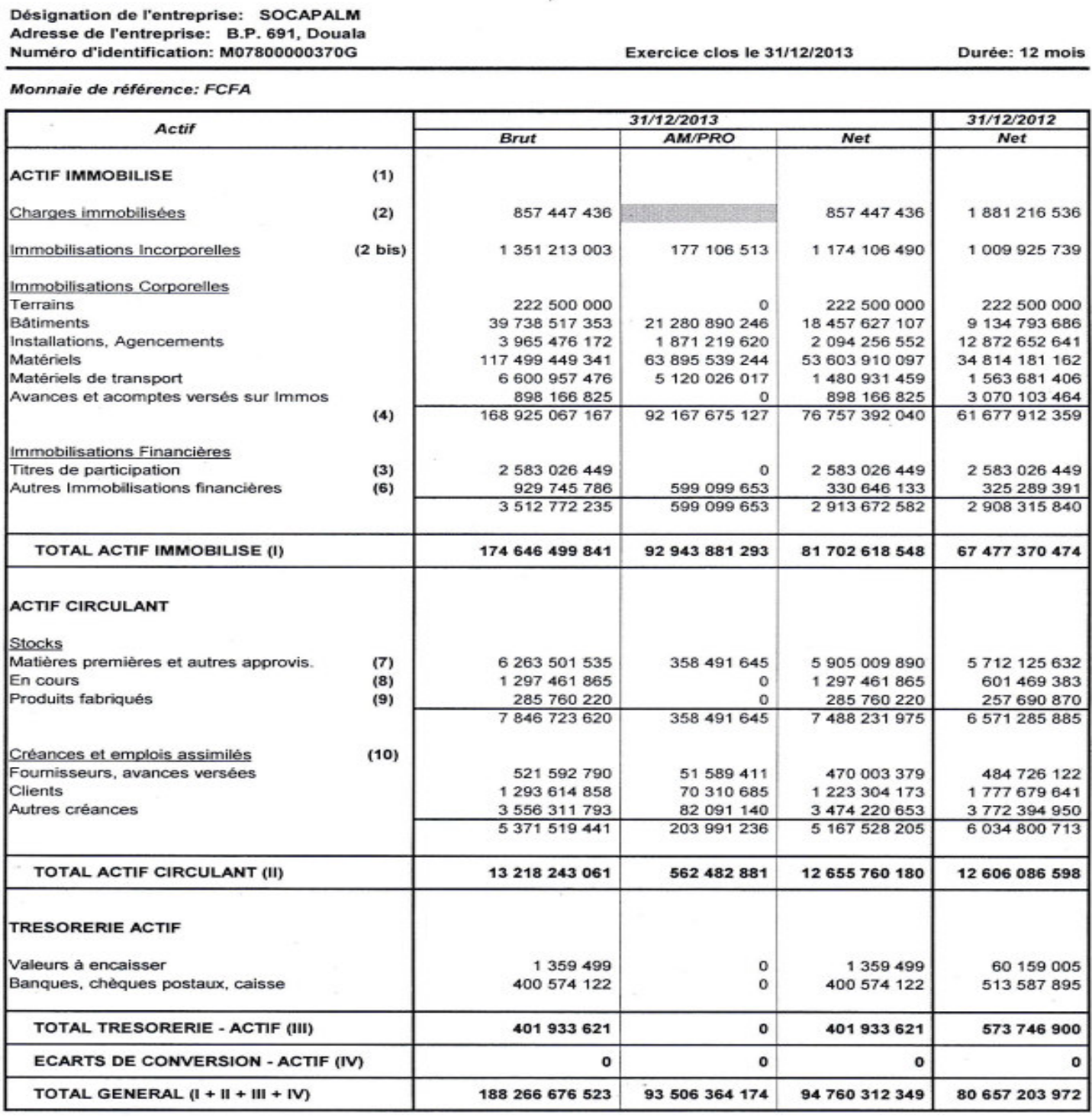

Source: DSX archives

Indeed, among the green information listed on the internet, none could be identified in the financial statements. However, financial information such as the value of capital, the amount of fixed assets, the result of the financial year, or other similar information is clearly identifiable in the financial statements. 
Table 3 : Extract of SAFACA income statement, year 2013.

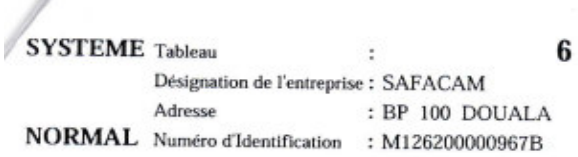

NORMAL Numéro dldentification : M126200000967B

Exercice clos le :

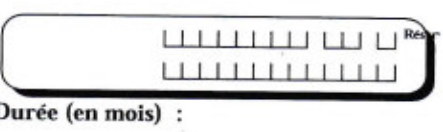

\begin{tabular}{|c|c|c|c|c|c|c|}
\hline \multicolumn{4}{|c|}{ Compte de résultat : Produits } & \multicolumn{2}{|l|}{$n$} & \multirow[b]{2}{*}{ Exercice $N-1$} \\
\hline Rér. & \multicolumn{3}{|c|}{ Rubriques } & 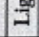 & Exercice N & \\
\hline & \multicolumn{3}{|l|}{ ACTIVITÉ D'EXPLOITATION } & 01 & & \\
\hline TA & \multicolumn{3}{|l|}{ Ventes de marchandises } & 02 & & \\
\hline TB & MARGE BRUTE SUR MARCHANDISES & & & 03 & & \\
\hline $\mathrm{TC}$ & \multicolumn{3}{|l|}{ Ventes de produits fabriqués } & 04 & 13027077715 & 12653799884 \\
\hline TD & \multicolumn{3}{|l|}{ Travaux, services vendus } & 05 & & \\
\hline TE & \multicolumn{3}{|l|}{ Production stockée (ou déstockage) } & 06 & 281590601 & 164281154 \\
\hline TF & \multicolumn{3}{|l|}{ Production immobilisée } & 07 & 1197329448 & 2564680129 \\
\hline TG & MARGE BRUTE SUR MATIĖRES & $13893747992 /$ & 15293911507 & 08 & & \\
\hline $\mathrm{TH}$ & \multicolumn{3}{|l|}{ Produits accessoires } & 09 & & \\
\hline $\mathrm{TI}$ & \multirow{2}{*}{$\begin{array}{c}\text { CHIFFRE D'AFFAIRES }^{(1)} \quad(T A+T C+T D+T H) \\
\text { (l) dont à l'exportation }\end{array}$} & 13027077715 & 12653799884 & 10 & & \\
\hline $\mathrm{TJ}$ & & $6847881085 /$ & 7359715296 & 11 & & \\
\hline TK & \multicolumn{3}{|l|}{ Subventions d'exploitation } & 12 & & \\
\hline $\mathrm{TL}$ & \multicolumn{3}{|l|}{ Autres produits } & 13 & 28318626 & 100472733 \\
\hline $\mathrm{TN}$ & \multicolumn{3}{|l|}{ VALEUR AJOUTÉE } & 14 & & \\
\hline TQ & EXCÉDENT BRUT D'EXPLOITATION & $6164991447 /$ & 7105487697 & 15 & & \\
\hline TS & \multicolumn{3}{|l|}{ Reprises de provisions } & 16 & & \\
\hline TT & \multicolumn{3}{|l|}{ Transferts de charges } & 17 & & \\
\hline TW & \multicolumn{3}{|l|}{ Total des produits d'exploitation } & 18 & 14534316390 & 15483233900 \\
\hline $\mathrm{TX}$ & RESULTAT D'EXPLOITATION & 4705674465 & 5834365930 & 19 & & \\
\hline & \multicolumn{3}{|l|}{ ACTIVITÉ FINANCIËRE } & 20 & & \\
\hline UA & \multicolumn{3}{|l|}{ Revenus financiers } & 21 & 166377522 & 225350416 \\
\hline UC & \multicolumn{3}{|l|}{ Gains de change } & 22 & & \\
\hline UD & \multicolumn{3}{|l|}{ Reprises de provisions } & 23 & & \\
\hline UE & \multicolumn{3}{|l|}{ Transferts de charges } & 24 & & \\
\hline UF & \multicolumn{3}{|l|}{ Total des produits financiers } & 25 & 166377522 & 225350416 \\
\hline UG & RÉSULTAT FINANCIER $(+$ ou -$)$ & $166377522 / /$ & 225350416 & 26 & & \\
\hline $\mathbf{U H}$ & \multicolumn{3}{|l|}{ Total des produits des activités ordinaires } & 27 & 14700693912 & 15708584316 \\
\hline \multirow{3}{*}{$\begin{array}{l}\text { UI } \\
\text { UJ }\end{array}$} & RESULTAT ACTIVITÉS ORDINAIRES (1) & 4872051987 & 6059716346 & 28 & & \\
\hline & (I) dont impôt correspondant & , & & 29 & & \\
\hline & Hors activitÉs ORDINAIRES (H.A.O.) & & & 30 & & \\
\hline UF & Produits des cessions d'immobilisations & & & 31 & 22803747 & 8200000 \\
\hline U & Produits H.A.O, & & & 32 & & \\
\hline us & Reprises H.A.O. & & & 33 & 109633849 & 51291593 \\
\hline UN & Transferts de charges & & & 34 & & \\
\hline UO & Total des produits H.A.O. & & & 35 & 132437596 & 59491593 \\
\hline UP & RESULTAT H.A.O. $(+$ ou -$)$ & 132437596 & 59491593 & 36 & & \\
\hline UT & TOTAL GÉNERAL DES PRODUTTS & & & 37 & 14833131508 & 15768075909 \\
\hline $\mathrm{UZ}$ & RÉSULTAT NET Bénéfice $(+)$; Perte $(-)$ & 2871838135 & 4363856457 & 38 & & \\
\hline
\end{tabular}

Source: DSX archives

At the end of this analysis, we draw the following conclusion: SYSCOHADA in its current form does not seem yet adapted to the accounting reporting of green information.

Indeed, SYSCOHADA allows the horizontal extension of the accounts and the adaptation of the labels according to the specificities of the operations and the companies. Nevertheless, the masses of accounts contained in the financial statements are standardized, and do not give companies leeway to distinguish green operations from conventional financial operations. And, in the analysis of the result from the income balances, there is no provision proposing aggregates to assess the societal performance of companies.

Moreover, even though SYSCOHADA has recently introduced innovations allowing [certain categories] of companies to provide [a certain number] of green information, it is nonetheless true that the form of communication proposed is far from be accountable. As proof, these innovations copied mainly on international 
standards have already been the subject of much criticism in prior literature. This type of communication of information on the basis of tables of quantities and narrative support has been taxed as "story telling" or "greenwashing" instrument, since it is difficult for them to be verified and compared. (Capron and Quairel, 2009, Bowen and Aragon-Correa, 2014).

However, the most promising forms of green information reporting are those that can integrate the rigor of financial reporting, appreciated for the reliability, verifiability and comparability of the data it provides (Ngantchou, 2015, Richard, 2012; Ramanathan, 1976).

In light of all these limitations of SYSCOHADA in communicating green information, it is not excluded that we will soon be witnessing another radical and brutal change in the uniform act.

\section{Conclusion}

At the end of this study, it appears that the report of green information is receiving increasing attention in the literature. Despite the existence of numerous standards offering tools and models for the evaluation and dissemination of green information, most of the solutions proposed are still ineffective. We have in this study distinguished on the one hand the solutions proposed by international standards such as the ISO 26000 standard and the guidelines of the Global Reporting Initiative (GRI), and that proposed by national or even regional reference standards. These accounting models offer companies tools to disseminate their green information. The problem we have highlighted in relation to solutions proposed by these standards is mainly based on the format of communication of the information. Thus, far from reflecting the standards of a financial accounting, these standards privilege the diffusion of green information, independently or at the same time as the financial statements, in the form of narrations, tables and quantities which move away from the standards of 'true accounting.

We completed this study with an emphasis on the OHADA accounting framework. After presenting the latter, an exploratory study was conducted with companies listed on the Douala stock exchange in Cameroon. In this study, which aimed to assess the capacity of OHADA to report on the social and environmental impact of companies, we have listed a set of data from the internet, which we have subsequently compared with the statements generated by companies listed on the DSX. This analysis shows that the financial statements produced using the OHADA framework do not yet enable the societal commitment of companies to be translated.

\section{References}

Ahmad R.A.R., Tower G., Plummer J. et Aripin N. (2010). Transparency and clarity of water accounting reporting. Journal of the Asia-Pacific Centre for Environmental Accountability 16 (4) : 4-19.

Alonso-Almeida M., Llach J. et Marimon F. (2014). A closer look at the 'Global Reporting Initiative'sustainability reporting as a tool to implement environmental and social policies: A worldwide sector analysis. Corporate Social Responsibility and Environmental Management 21 (6) : 318-335.

Blin-Franchomme M.-P. (2010). Le droit économique au soutien de la protection de l'environnement: les apports de la loi Grenelle 2 à la gouvernance des entreprises et des consommateurs. Revue juridique de l'environnement (5) : 129-176.

Blin-Franchomme M.-P. et Desbarats I. (2010). Droit du travail et droit de l'environnement: Regards croisés sur le développement durable, Wolters Kluwer France.

Blin-Franchomme M.-P., Desbarats I. et Jazottes G. (2011). Entreprise et développement durable: approche juridique pour l'acteur économique du XXIe siècle, Wolters Kluwer France.

Bowen F. et Aragon-Correa J.A. (2014). Greenwashing in corporate environmentalism research and practice: The importance of what we say and do, SAGE Publications Sage CA: Los Angeles, CA.

Bowen H.R. (1953). Social responsibilities of the businessman, Harper.

Brundtland G.H. (1987). Our common future - Call for action. Environmental Conservation 14 (4) : 291-294.

Capron M. et Quairel F. (2009). Le rapportage «développement durable » entre reddition et communication, entre volontariat et obligation. Revue de l'organisation responsable 4 (2) : 19.

Carroll L. (2008). A review of the relevance of demography to Australian water planning. Journal of Population Research 25 (2) : 119-139.

Chalmers K., Godfrey J. et Potter B. (2012). Discipline-Informed Approaches to Water Accounting. Australian Accounting Review 22 (3) : 275-285.

Chauvey J.-N. (2010). Hypocrisie, déraison : les nouveaux leviers du contrôle ? Comptabilité - Contrôle - Audit $16(1): 33$.

Chauvey J.-N. et Naro G. (2013). Reporting Et Pilotage Societaux: Repenser La Performance Globale A L'Aune Des Paradoxes De La Rse. In Comptabilité sans Frontières... The French Connection. : cd-rom.

Chauvey J.-N., Naro G. et Seignour A. (2015). Rhetorique et mythe de la Performance Globale L'analyse des discours de la Global Reporting Initiative. Critical Perspectives on Accounting 33 : 79-91.

Chelli M. (2015). Trois études sur la mesure de la performance des entreprises en matière de développement 
durable: pouvoir disciplinaire et légitimation. Université Laval.

Chelli M. et Gendron Y. (2015). L'expertise en évaluation socio-environnementale des entreprises: légitimation et mises à l'épreuve. Comptabilité-Contrôle-Audit 21 (2) : 63-96.

Damak Ayadi S. (2006). Analyse des facteurs explicatifs de la publication des rapports sociétaux en France. Comptabilité - Contrôle - Audit 12 (2) : 93.

Damak-Ayadi S. (2010). Le reporting social et environnemental suite à l'application de la loi NRE en France. Comptabilité - Contrôle - Audit 16 (1) : 53.

Diawara K. et Lavallée S. (2014). Corporate Social Responsibility (CSR) in the Ohada Law. Journal of Business Law and Ethics 2 (2) : 39-62.

Edwards G.A. (2013). Shifting constructions of scarcity and the neoliberalization of Australian water governance. Environment and Planning A 45 (8) : 1873-1890.

Friedman M. (1971). Does business have a social responsibility. Bank Administration 47 (4) : 13-14.

Godfrey J.M. et Chalmers K. (2012). Water accounting: International approaches to policy and decision-making, Edward Elgar Publishing.

Gray R. (2010). Is accounting for sustainability actually accounting for sustainability... and how would we know? An exploration of narratives of organisations and the planet. Accounting, organizations and society 35 (1) : 47-62.

Gray R., Owen D. et Adams C. (1996). Accounting \& accountability: changes and challenges in corporate social and environmental reporting, Prentice Hall.

Grimand A., Vandangeon-Demurez I. et Schaefer P. (2014). Manager les paradoxes de la RSE. Le déploiement de la norme ISO 26000 dans une ETI. Revue française de gestion 40 (240) : 133-148.

Hahn R. et Lülfs R. (2014). Legitimizing Negative Aspects in GRI-Oriented Sustainability Reporting: A Qualitative Analysis of Corporate Disclosure Strategies. Journal of Business Ethics 123 (3) : 401-420.

Marimon F., del Mar Alonso-Almeida M., del Pilar Rodríguez M. et Alejandro K.A.C. (2012). The worldwide diffusion of the global reporting initiative: what is the point? Journal of Cleaner Production 33 : $132-144$.

Milne M.J. et Gray R. (2013). W (h) ither ecology? The triple bottom line, the global reporting initiative, and corporate sustainability reporting. Journal of business ethics 118 (1) : 13-29.

Moskolaï D.D., Tsapi V. et Feudjo J.R. (2016). État des lieux de la Responsabilité Sociétale des Entreprises au Cameroun. Management \& Avenir (4) : 139-162.

Ndjetcheu L. (2013). Social Responsibility and Legal Financial Communication in African Companies in the South of the Sahara: Glance from the OHADA Accounting Law Viewpoint. International Journal of Innovation in the Digital Economy (IJIDE) 4 (4) : 1-17.

Ngantchou A. (2015). Rendre Compte De L'Engagement Social Et Environnemental De L'Entreprise Par Les Comptes: Contribution Pour Un Cadre Conceptuel De Comptabilite Sociale Et Environnementale. In Comptabilité, Contrôle et Audit des invisibles, de l'informel et de l'imprévisible. : cd-rom.

Petit F. et Belet D. (2013). Tentative d'une «comptabilité élargie» à la responsabilité sociétale de l'entreprise ou comment concilier business et intérêt général? Recherches en Sciences de Gestion (1) : 29-51.

Pigram J. (2007). Australia's water resources: from use to management, CSIRO publishing.

Ramanathan K.V. (1976). Toward a theory of corporate social accounting. The Accounting Review 51 (3) : $516-$ 528.

Richard J. (2012). Comptabilité et développement durable,

Safari K. et Nathalie N.B. (2018). Application of the OHADA Accounting System by Companies in DRC, Current Status and Prospects: Case of the City of Bukavu. Journal of Accounting, Finance and Auditing Studies 4 (1) : 93-107.

Sethi S.P. (1979). A conceptual framework for environmental analysis of social issues and evaluation of business response patterns. Academy of Management Review 4 (1) : 63-74.

Slattery M., Chalmers K. et Godfrey J.M. (2012). Beyond the hydrographers' legacy: water accounting in Australia. Water Accounting: International Approaches to Policy and Decision-Making, Edward Elgar Publishing Limited, Gloucester : 17-31.

Sofocleous S. (2010). Will water accounting standards provide useful information to stakeholders? Interdisciplinary Environmental Review 11 (4) : 293-302.

Takafo-Kenfack D. (2018). La réforme de l'alerte et de l'expertise de gestion dans le nouveau droit OHADA des sociétés commerciales: une entreprise inachevée! Uniform Law Review 23 (1) : 81-98.

Tello E., Hazelton J. et Cummings L. (2016). Potential users' perceptions of general purpose water accounting reports. Accounting, Auditing \& Accountability Journal 29 (1) : 80-110.

Vardon M. et Peevor S. (2004). Water accounting in Australia: use and policy relevance. London Group on Environmental Accounting, Copenhagen, Denmark. 